\title{
The Value of Kindness and Responsibility Character Education in Teacher-Student Relationships in the Novel of Guru Aini by Andrea Hirata
}

\author{
Jaki Yudin; Suyitno; Muhammad Rohmadi \\ Master Program of Indonesian Language Education, Sebelas Maret University, Surakarta, Indonesia \\ http://dx.doi.org/10.18415/ijmmu.v8i2.2403
}

\begin{abstract}
Character education is an effort to reinforce character values to create Indonesia's golden generation. This study aimed to describe and explain the educational value of goodness and responsibility character in the novel of Guru Aini. The data in this study are data on the values of character education in the form of dialogue quotes, sentences, and paragraphs in novels. The data source is the novel Guru Aini by Andrea Hirata. The data collection technique which is used is documentation techniques with reading, recording, and assessment activities. The validation technique used theory triangulation and data triangulation. The data analysis technique used an interactive model analysis technique which includes three components, namely: (1) data reduction; (2) data presentation; and (3) drawing conclusions. The results showed that the novel contains the educational value of good character related to giving, such as giving appreciation, forgiveness, knowledge, and goods. Meanwhile, the educational value of the responsibility character reflected that a more responsible attitude as a teacher and a student. The novel of Guru Aini can be used as a media for giving the values of character education.
\end{abstract}

Keywords: Character Education; Kindness; Responsibility

\section{Introduction}

Indonesia as a developing country have to continue in improving the golden generation in 2045 . Strengthening the character foundation needs to be instilled in order to avoid negative impacts and behaviors that can make slow down the formation of the nation's golden generation. However, the efforts to strengthen character do not seem to have met expectations. The reason is, the fading of the character values that become the national identity is worrying increasingly. One form of the fading of the nation's character can be seen from the increasing of corruption that often occurs and the lack of awareness of differences, namely ethnicity, religion, race and group in Indonesia (Komariah, Kurniatun, \& Almubaroq, 2019).

In addition, young people who become the nation's next generation do not show good behavior. Juvenile delinquency is much influenced by the presence of technology and easy access to information as well as the weak role of the educational trip center. As a result, criminal behavior, both individuals and 
groups, comes from various elements of society. Individual crimes and youth moral decline, both from the upper and lower classes, need to be given a solution through educational character (Sulyati, 2020).

Character education is intended to form morals through the process, knowing well, loving good, and behaving well so that good morals can be implemented into habits of mind, heart and hands (Albantani, 2015). Character education is a system of cultivating character values which includes components of knowledge, awareness or willingness, and actions to carry out these values (Tyas, Sunarto, \& Naibaho, 2020). In this regard, Abourjilie (2006: 2) stated that character education is a national movement that creates schools that foster ethical, responsible, and caring young people by setting an example and teaching good character through an emphasis on universal values that we share.

The value of character education that needs to be strengthened is the character value of kindness and responsibility. Kindness is a condition and action that can be accepted by society because it deserves to be accepted humanity and can provide comfort for them (Fauziah, 2019); Kindness helps children to show concern for the welfare and feelings of others (Marzuki, 2017: 58). Kindness can include behaviors such as being considerate, polite, helpful and understanding of others. Shows compassionate concern, friendship, and generosity. Treat others as you want to be treated (Abourjilie, 2006: 15). Therefore, the value of good character education can play a role in inhibiting the emergence of evil intentions or immoral actions because it can provide comfort and respect for fellow humans.

The Ministry of National Education (2010) provides an explanation that responsibility is a person's attitude and behavior to carry out his duties and obligations, which he should do for himself, society, the environment (natural, social, and cultural), the country, and God Almighty. In addition, responsibility can be interpreted as an act carried out by each individual based on his obligations and hearts, namely an attitude that shows that a person has a high caring nature (Sulaeman, Goziyah, Purawinangun, \& Noermanzah, 2020). Several indicators of the character of responsibility include being reliable in carrying out obligations and duties. Show reliability and consistency in speech and behavior. Responsible for their own actions and committed to be actively involved in the community (Abourjilie, 2006: 15). Thus, the value of the character of responsibility can awaken a person to carry out his obligations so as to kill the seeds of corrupt behavior.

The efforts to strengthen character education can be pursued through literature learning. Literature is able to shape human intellect and character abilities. Initially, literature was able to form personal competence and character and finally it could also form competence and personal character socially (Suyitno, 2014: 107). The pluralistic and socio-cultural aspects of literature have great potential to develop character education (Ali Imron \& Nugrahani, 2019). Therefore, literature review needs to be done to find out the values of character education in it.

Novel is a type of literary work in the form of prose. A novel can be considered as a literary work that talks about a person's life journey (Bennett \& Royle, 2009: 38). Novels are able to present the development of one-character, complex social situations, relationships that involve many or a few characters and various complex events that occurred several years ago in detail (Stanton, 2012: 33). Characters are built by certain basic combinations of fictional elements in the form of language, description, action, dialogue, and interactions with other scenes and characters (Cassill, 1992: 156). Based on this explanation, characters have an important role in accommodating the value of character education through their relationships with other characters and the events they face in the novel.

The novel entitled Guru Aini by Andrea Hirata tells about a teacher's journey in teaching mathematics in remote areas. The teacher then met a student who was ignorant of mathematics. Over time, these encounters formed a meaningful teacher-student relationship. As usual, Andrea Hirata always writes novels with social themes related to education and economics. Andrea Hirata's world view that is 
expressed is able to represent the social conditions and realities of life of the Indonesian people, most of whom still live in poverty, experience social inequality, and educational inequality (Kadir, 2013). Therefore, Andrea Hirata's novels are interesting to study the value of education, especially Guru Aini's novel, which contains the relationship between teacher and student.

Research on character education has been conducted before such asIrma (2018)) who conducted research on novels that had character education values and recommended a novel entitled Ibuk for character development of students in schools. Furthermore, Koswara, Isnendes, Ruhaliah, \& Suherman (2020), in their research found the values of character education in children's novels entitled Guha Karang Legok Pari which are based on the local wisdom of the Sundanese people. Meanwhile, Zainuddin, Waluyo, \& Saifudin (2020), provide an alternative effort to develop the value of responsibility with the "Makan Kembul" learning model to make teachers more independent and creative in choosing which patterns are most liked by students and students are more likely to interact in learning. Based on previous research, research on the value of goodness and responsibility character education in teacherstudent relationships can complement efforts to instill character values to support Indonesia's golden generation.

\section{Research Method}

This study uses a qualitative descriptive method so the researcher must collect their own data through examining documents, observing behavior, or interviewing participants / people (Creswell, 2009: 175). In this study, the data are data on the values of character education in the form of dialogue quotes, sentences, and paragraphs in novels. The data source is the novel Guru Aini by Andrea Hirata. The data collection technique uses documentation techniques with reading, recording, and assessment activities. The validation technique used is the theory triangulation and data triangulation. The data analysis technique in this study used an interactive model analysis technique which is included three stages, namely: (1) data reduction; (2) data presentation; and (3) drawing conclusions (Miles \& Huberman, 1992: 16-20).

\section{Results and Discussion}

In the novel Guru Aini by Andrea Hirata, there is a close relationship between teachers and students. This relationship is represented by the figure Desi Istiqomah as a teacher and Aini as a student. Aini is a very influential figure in the realization of Teacher Desi's idealism. Aini is a student who is ignorant of mathematics and is motivated to be able to master mathematics because her father is suffering from an illness. Aini wants to cure her father by trying to be able to go to medical school. One of the ways is to learn mathematics with Teacher Desi who is known to be smart and hard in teaching mathematics. In the teacher-student relationship, there is a character education value of kindness and responsibility that is accommodated by the two figures.

\section{Teacher-Student Relationships in the Novel Guru Aini}

The meeting between Teacher Desi and Aini was an intentional meeting by Aini who was about to move to Teacher Desi's class. After moving, Teacher Desi was confused about teaching mathematics to Aini. Teacher Desi was even frustrated that she couldn't teach math to Aini, so she tried to return Aini to the Teacher Tabah class. However, Teacher Desi was amazed by Aini's strong desire and enthusiasm for studying mathematics. Aini even tried to increase her study hours with Teacher Desi by coming to her official home after school hours. 
It was so difficult for Teacher Desi to teach mathematics to Aini even though she had given her all. In addition, Teacher Desi has been angry and cursed at Aini many times and even kicked her out. However, Aini kept coming again and again to Teacher Desi's house. The more Teacher Desi shouted and blamed her, the more Aini's spirit burned. This made his idealism shaken that he had failed to become a mathematics teacher. He became increasingly aware that no one has the right to prohibit a child's desire to learn.

Teacher Desi also realized that if She failed to make Aini able to do math, he would also fail to become a math teacher. So, she tried various ways that could make Aini understand mathematics. Until finally, Teacher Desi found her by teaching Aini "calculus". Slowly but surely Aini's progress was increasingly visible from her better test scores. Until finally Teacher Desi was sure that Aini was a child from a rural area of Ketumbi whom she had been looking for to be guided and made a math-smart child. After what she had been through with Aini, Teacher Desi decided to fulfill her promise to replace her shoes from her father had given to her with new ones when she had found a child who was smart in mathematics.

Teacher Desi's relationship with Aini is the relationship between a teacher's beliefs and a student's persistence. The two of them blend into one to form a strong emotional closeness. The achievement of Teacher Desi with her idealism was fulfilled by Aini's presence. Meanwhile, Aini's achievement in being able to be smart in mathematics and being accepted into the medical faculty was due to the skill and intelligence of Teacher Desi. Teacher Desi is a hero character who brings the author's worldview related to education and mathematics in remote communities.

\section{The Value of Kindness Character Education}

The value of goodness character education is a state of the heart that triggers good deeds or actions towards others such as like helping or giving, caring, being generous, treating people well and others. The value of good character education in Guru Aini's novel is described as follows:

[Data Description and Discussion 1]

Teacher Desi is a teacher who highly values honesty. That also made Teacher Desi want to accept Aini to move to her class to study mathematics. Since joining Teacher Desi's class, Aini has been the student with the lowest score on her math test. However, in a math test the value goes up even though only slightly. Teacher Desi was kind enough to give additional marks for Aini's strategy in dealing with math tests. It is contained in the following quotation.

"Baiklah kujelaskan, nilai setengah itu adalah penghargaanku untuk strategi jitumu itu!"

"Te..terima kasih banyak, Bu, terima kasih banyak." (Hirata, 2020: 149)

"Well let me explain, that half value is my reward for your exact strategy!"

"Th ... thank you very much, Mom, thank you very much." (Hirata, 2020: 149)

The value of good character education from the quote above is the kindness of a teacher in order to give an appreciation for the efforts made by her students. Such small kindness can motivate students to study even harder. The value of kindness needs to be nurtured and exemplified by teachers to their students. It is very important to build self-confidence, respect, and achievement motivation.

[Data Description and Discussion 2]

Teacher Desi was angry with Aini because she had been teaching mathematics for more than a month but there is no progress. Because, Aini was so wrong in answering the questions given as Aini's assignment from Teacher Desi. Even though this question is equivalent to a question for 1 grade junior high school student, Teacher Desi shredded Aini's answer paper and threw it through her window. Feeling 
guilty for her actions, Teacher Desi apologized to Aini. Instead, she realized that Teacher Desi's actions were due to her stupidity. It is contained in the following quotation.

"Maafkan aku kemarin, Boi."

Kata Guru pada Aini. Diserahkannya potongan-potongan kertas jawaban Aini itu. Aini tersenyum.

"Tak perlulah Ibu minta maaf, akulah yang harus minta maaf karena aku bodoh sekali." (Hirata, 2020: 186)

"I'm sorry yesterday, Boi."

Teacher said to Aini. She handed over the pieces of Aini's answer paper. Aini smiled.

"You don't need to be sorry, I'm the one who should apologize because I'm so stupid." (Hirata, 2020: 186)

The kindness described in the quote above is the kindness of a humble child. The value of kindness to always forgive the actions of others and self-introspection are very important for someone to have. Especially for someone who is really needed to achieve her goals. Such kindness values are needed to build a student's character. With a character that is full of kindness, a harmonious relationship will be built so that it can prevent conflict.

[Data Description and Discussion 3]

After struggling with mathematics for a long time, Aini finally succeeded in becoming someone who could conquer mathematics. This is the extraordinary achievement of Aini's character, from being a weak mathematician to be a smarter mathematician. The struggle that was not easily accompanied by sweat and tears finally paid off. Now, Aini spreads this knowledge to children in need near where she lives. It is contained in the following quotation.

Murid-murid Aini adalah belasan anak-anak pasar yang kumal yang ada dilingkungannya. Dikumpulkannya di rumahnya anak-anak yang sehari-hari membantu orang tua mereka berjualan di kaki lima, berjualan bakso, bubur ayam, menyemir sepatu atau mengamen... (Hirata, 2020: 267)

Aini's students are dozens of ragged market children in her neighborhood. She collected at her house the children who daily help their parents selling on the sidewalks, selling meatballs, chicken porridge, shining shoes or busking ... (Hirata, 2020: 267)

The value of good character education to spread knowledge is a noble act. The action taken by Aini's character is a real action of a school student who participates in educating disadvantaged children. Kindness that is based on sincerity can provide benefits for others and the surrounding environment. Therefore, the value of good character education also has a positive impact on the social environment, especially in this case, voluntary educational service assistance.

[Data Description and Discussion 4]

Aini has transformed into a smart student and graduated from high school with the third best graduate status. Furthermore, she had to struggle to pass the medical faculty entrance test. Her three years of struggle with the best teacher will be at stake for his goal of becoming a doctor. Now is the time to prove Aini in the battle for a place in the medical faculty of a state university. Her departure for admission to medical school served as a reminder of his past life. This is illustrated in the following quote.

Aini telah siap. Dia menyandang tas kecil dan memanggul backpack yang besar. Backpack yang dulu dipakai Guru Desi saat pertama berangkat merantau. Aini pun bersepatu dan berbaju Muslimah yang dibelikan Guru Desi. Melihat Aini, Guru Desi seakan melihat dirinya sendiri, dalam versi yang lebih kecil. (Hirata, 2020: 273) 
Aini is ready. She carried a small bag and shouldered a large backpack. The backpack that Teacher Desi used to use when he first went overseas. Aini also had shoes and a Muslim dress that Teacher

Desi had bought. Seeing Aini, Teacher Desi seemed to see herself, in a smaller version. (Hirata, 2020: 273)

The good character represented by Teacher Desi in the quote is in the form of giving something. The value of the kindness of giving or helping each other is human identity as a social being. By having a good character, problems that prevent a person from reaching their dreams can be minimized through gifts, whether in the form of money, goods, food, energy and so on. Therefore, someone needs to have the value of kindness to others so that they can strengthen relationships between humans.

\section{The Value of Responsibility Character Education}

The value of responsible character education is attitude and behavior that is reliable and full of commitment in carrying out its obligations to oneself, others, and the surrounding community. The value of responsibility character education in Guru Aini's novel is described as follows.

\section{[Data Description and Discussion 5]}

As a teacher, Desi Istiqomah has the responsibility to educate the lives of the nation's children. One of them is through a teacher service program after being sworn in. Desi Istiqomah serves on Tanjong Hampar Island, precisely in Ketumbi Village which is very far away. After years of service, Desi Istiqomah has never been transferred to a place closer to her family. This is because she still has to be responsible for teaching mathematics because there has not been any change or improvement in her intelligence during her service. It is contained in the following quotation.

Desi Istiqomah tak mau meninggalkan anak-anak Kampung Ketumbi dalam keadaan jahiliah matematika seperti dia baru datang ke kampung itu bertahun-tahun yang silam. (Hirata, 2020: 52).

Desi Istiqomah did not want to leave the children of Ketumbi Village in a state of ignorance of mathematics as if she had just come to the village many years ago. (Hirata, 2020: 52).

The value of responsible character education in Desi Istiqomah's character is a representation of a teacher who has a real educator spirit. The responsibility that must be resolved is in the form of selfbenefit in the new social environment. The value of such responsibility is important for someone to think and act to change something for the better than before. In this case, the existence of a person must have a positive impact on both others and the surrounding environment. The value of the character of responsibility can form concern for others and can work in totality for the mandate that has been given.

\section{[Data Description and Discussion 6]}

Many years of dedication in Ketumbi Village brought Teacher Desi to her meeting with a student named Aini. A student who can't do math and tries to study math with her. However, Teacher Desi always finds it difficult to teach Aini mathematics because she almost never really understands it. The value of responsibility as a teacher is tested by this situation. Desi teacher tries to take responsibility to make Aini able to do math with various kinds of ideas and learning methods. This is implicitly illustrated in the following quotation.

Selama ini Guru mengajar Aini dengan cara pandang bahwa bangunan matematika dalam diri anak itu telah runtuh lalu Guru berusaha mendirikan lagi bangunan yang runtuh itu. Kini, Guru akan mencoba strategi baru. Dia akan meninggalkan bangunan runtuh itu, dan akan membangun bangunan baru. (Hirata, 2020: 185) 
All this time, the Teacher taught Aini with the perspective that the math building in the child had collapsed and the Teacher tried to rebuild the collapsed building. Now, the Teacher will try a new strategy. She will leave the collapsed building, and will build a new one. (Hirata, 2020: 185)

The responsibility of a teacher is truly represented by the figure of Teacher Desi. This form of responsibility can mean that no matter how difficult the situation is, never give up and keep trying. In other words, if the character of responsibility is inherent in someone, it will give more efforts to solve the problem. From the character of Teacher Desi, it can be understood that the value of responsible character education can make someone more motivated, give their best, never give up, and dare to try new things.

[Data Description and Discussion 7]

The reason why Aini wants to become a master of mathematics is that she feels responsible for her sick father. According to doctors, her father could only be cured by medical science. This is Aini's big motivation in learning so that later she can cure her father's illness. This wish has been conveyed to Teacher Desi in the following quote.

"Aku harus bisa masuk fakultas kedokteran, Bu. Apa pun yang terjadi, aku harus bisa masuk fakultas kedokteran. Aku anak ayahku, Bu, ayahku adalah tanggung jawabku." (Hirata, 2020: 180)

"I have to be able to enter medical school, Mom. No matter what happen, I should be able to enter medical school. I am my father's daughter, Mom, my father is my responsibility." (Hirata,2020: 180)

The value of responsible character education through the character Aini is proof of a child's love for her father. By having such a responsibility, a child will be devoted to her parents. This form of devotion to parents can be done through various things such as studying hard, caring for them when they are sick, easing the work of parents and others. Therefore, the value of responsible character education needs to be instilled from an early age so that one day it can help families wholeheartedly.

[Data Description and Discussion 8]

Aini's persistence in studying until the sweat and tears paid off. However, considering that the journey to the medical faculty is still continuing because Aini has only mastered mathematics thanks to the guidance of Teacher Desi. After successfully conquering mathematics, Aini has the responsibility given by Teacher Desi to teach mathematics to anyone who needs it.

Aini telah mencapai moral tertinggi belajar. Matematika telah memukulinya selama bertahuntahun sehingga dia babak belur. Kini dia telah belajar cara belajar matematika dan dia bangkit untuk menuntut balas. Dia melaksanakan amanah Guru Desi, yaitu mengajar matematika pada siapa saja yang memerlukan. MLM kecerdasan, kata Guru. (Hirata, 2020: 267)

Aini has reached the highest moral learning. Math had beat her for years so badly she was battered. Now she has learned how to learn mathematics and she gets up to seek revenge. She carried out the mandate of Teacher Desi, namely teaching mathematics to anyone who needed it. MLM intelligence, said Teacher. (Hirata, 2020: 267)

The character of a person's responsibility can emerge if given the trust of those who contributed to her life. From that sense of responsibility, it then produces positive actions needed by others. Not only limited to practicing belief but more than that is spreading goodness. Thus, the value of responsible character education needs to be owned by someone in order to spread goodness through the mandate that has been given to her. 


\section{Conclusion}

Based on the explanation of the results and discussions that have been described, in the novel Guru Aini by Andrea Hirata there is a relationship between teacher and student. This relationship is represented by the figures of Teacher Desi and Aini who accommodate the values of character education for kindness and responsibility. The value of good character education is related to giving, such as giving appreciation, forgiveness, knowledge, and goods. Meanwhile, the value of the character of responsibility education reflects a more responsible attitude as a teacher and a student. Thus, the novel Guru Aini can be used in literature learning as an effort to cultivate the values of character education.

\section{References}

Abourjilie, C. (2006). Character Education Informational Handbook and Guide II. North Carolina: Department of Public Instruction.

Albantani, A. M. (2015). Preparing The Future Leaders through Character Education. The 2nd International Conference on Education in Muslim Society, 393-403. Jakarta.

Ali Imron, A. M., \& Nugrahani, F. (2019). Strengthening pluralism in literature learning for character education of school students. Humanities and Social Sciences Reviews. https://doi.org/10.18510/hssr.2019.7332

Bennett, A., \& Royle, N. (2009). An Introduction of Literature, Criticism, and Theory. London: Pearson. Cassill, R. V. (1992). Writing Fiction (Second). New York: Prentice Hall Press.

Creswell, J. W. (2009). Research Design: Qualitative, Quantitative and Mixed Approaches (3rd Edition). In Research Design: Qualitative, Quantitative, and Mixed Methods Approaches. https://doi.org/10.2307/1523157

Fauziah, M. (2019). Konsep Kebaikan dalam Perspektif Dakwah. AL-IDARAH: Jurnal Manajemen Dan Administrasi Islam, 3(1), 73-94.

Hirata, A. (2020). Guru Aini. Yogyakarta: Bentang.

Irma, C. N. (2018). Nilai-Nilai Pendidikan Karakter dalam Novel Ibuk Karya Iwan Setyawan. RETORIKA: Jurnal Bahasa, Sastra Dan Pengajarannya Be, 11(1), 14-22. https://doi.org/10.26858/retorika.v11i1.4888

Kadir, H. (2013). Ekspresi Pandangan Dunia Kelompok Sosial Pengarang dalam Novel Laskar Pelangi Karya Andrea Hirata. Litera, 12(1), 129-145. https://doi.org/10.21831/1tr.v12i01.1336

Kementerian Pendidikan Nasional. (2010). Pengembangan Pendidikan Budaya dan Karakter Bangsa. Jakarta: Kemendiknas Balitbang.

Komariah, A., Kurniatun, T. C., \& Almubaroq, H. Z. (2019). The Role of Character Education Toward National Values Actualization. 3rd International Conference on Research of Educational Administration and Management, 307-309.

Koswara, D., Isnendes, R., Ruhaliah, \& Suherman, A. (2020). The Values of Character Education in Children's Novel Guha Karang Legok Pari Works of Hidayat Susanto. 4th International Conference on Language, Literature, Culture, and Education, 149-154.

Marzuki. (2017). Pendidikan Karakter Islam. Jakarta: Amzah.

Miles, M. B., \& Huberman, M. A. (1992). Analisis Data Kualitatif (T. R. Rosidi, ed.). Jakarta: UI Press.

Stanton, R. (2012). Teori Fiksi (Sugihastuti, ed.). Yogyakarta: Pustaka Pelajar.

Sulaeman, A., Goziyah, Purawinangun, I. A., \& Noermanzah. (2020). Social Value in The Novel Hatta: Aku Datang Karena Sejarah by Sergius Sutanto as Teaching Materials in Teaching Literature in Schools. International Journal of Scientific and Technology Research. https://doi.org/10.31219/osf.io/yxt6q

Sulyati, E. (2020). Character Education and Language. International Journal of Science and Society, 2(1), $255-266$.

Suyitno. (2014). Kajian Novel dalam Spektroskop Feminisme dan Nilai Pendidikan. Yogyakarta: Graha Ilmu. 
Tyas, E. H., Sunarto, \& Naibaho, L. (2020). Building Superior Human Resources through Character Education. Test Engineering and Management, 83(March-April), 11864-11873.

Zainuddin, H. M., Waluyo, B., \& Saifudin, A. (2020). Developing Character by Applying the Model of “ Makan Kembul " to Grow Attitudes of Independence, Togetherness, Responsibility, and Respect for Others . https://doi.org/10.2991/assehr.k.201112.040

\section{Copyrights}

Copyright for this article is retained by the author(s), with first publication rights granted to the journal.

This is an open-access article distributed under the terms and conditions of the Creative Commons Attribution license (http://creativecommons.org/licenses/by/4.0/). 